\title{
JULIA MURRMANN
}

Uniwersytet Warszawski, Warszawa

\section{TERMIN KULTURA FIZYCZNA Z PERSPEKTYWY SOCJOLINGWISTYCZNEJ}

Słowa kluczowe: kultura fizyczna, kultura, sport, język, socjolingwistyka.

\section{STRESZCZENIE}

Artykuł prezentuje wyniki badań nad etymologią, historią, znaczeniem i zakresem terminu kultura fizyczna, a także jego wspólczesnym wykorzystaniem w różnych kontekstach społecznych i w wybranych językach objętych analizą (polski, angielski, niemiecki, francuski i wloski, sporadycznie inne języki). Na podstawie przeprowadzonej analizy stwierdza się, że owo najbardziej kompleksowe, najbardziej pojemne semantycznie, nadrzędne pojęcie na określenie wszelkich działań podejmowanych dla rozwoju psychofizycznego oraz $\mathrm{w}$ ramach troski o ciało $\mathrm{i}$ zdrowie jest stopniowo wypierane $\mathrm{i}$ zastępowane przez „falszywe” synonimy i hiponimy.

\section{WPROWADZENIE}

W nawiązaniu do oryginalnej koncepcji pedagoga i filozofa Andrzeja Pawluckiego (2015), formulującego nowy paradygmat w obszarze refleksji dotyczącej nauki o kulturze fizycznej ${ }^{1}$, niniejszy artykuł należy rozumieć jako rezultat rozważań językoznawcy, a dokładniej socjolingwisty, nad interpretacją i funkcjonowaniem pojęcia kultury fizycznej. Skupiono się na etymologii, historii, znaczeniu, zakresie oraz współczesnym użyciu nazwy kultura fizyczna w różnych kontekstach spolecznych i w arbitralnie wybranych językach objętych analizą (polskim, angielskim, niemieckim, francuskim i wloskim oraz sporadycznie innych).

Przesłanką do podjęcia badań w tym zakresie bylo to, iż pojęcie kultura fizyczna, obecne w literaturze przedmiotu od ponad stu lat $\mathrm{i}$ teoretycznie mocno zakorzenione w tradycji badań nad motorycznością (fizycznością) czlowieka, zdaje się nie opuszczać strefy naukowego dy skursu akademickiego (i to w dużej mierze rozważań teoretycznych m.in. polskich badaczy) i być stopniowo - aczkolwiek systematycznie - wypierane (zarówno w fachowej literaturze przedmiotu, jak i w kontekstach potocznych i publicz-

\footnotetext{
${ }^{1} \mathrm{~W}$. dużym uproszczeniu propozycja Pawhuckiego sprowadza się do stwierdzenia, iż najrzetelniejsze badania w zakresie kultury fizycznej prowadzić powinni specjaliści od poszczegỏlnych dziedzin, rozparcelowując ten obszar między siebie i tworząc specjalizacje szczegółowe, czyli np. socjologowie — socjologia kultury fizycznej, psychologowie - psychologia kultury fizycznej, filozofowie - filozofia kultury fizycznej, pedagodzy - pedagogika kultury fizycznej.
} 
nych) przez inne konkurencyjne terminy, wykorzystywane poprawnie lub w sposób nie do końca uprawniony.

W pierwszej części artykułu podjęto próbę ustalenia proweniencji samego pojęcia kultura fizyczna oraz jego ewolucji: od momentu (przypuszczalnie) pierwszego użycia poprzez stadium terminu bardzo chętnie wykorzystywanego w pewnym konkretnym reżimie politycznym aż po okres (świadomej) rezygnacji i zastapienia go innymi pojęciami w wielu środowiskach i kontekstach spolecznych. Dalej zebrano i omówiono wybrane definicje kultury fizycznej, wskazując na niejasne i rozmyte granice znaczenia i zakresu tego terminu i tym samym uwidaczniając panujący chaos pojęciowy. Ponadto w artykule dokonano przeglądu wspólczesnych użyć terminu kultura fizyczna i innych (bliskoznacznych, zawierających się wewnątrz, fałszywie synonimicznych itd.) w różnych kontekstach życia spolecznego.

\section{ETYMOLOGIA POJECIA KULTURA FIZYCZNA}

Etymologicznie pojęcie kultura fizyczna należy wyprowadzić od dwóch slów obcej proweniencji, przy czym obecnie oba czlony funkcjonują autonomicznie w języku polskim (podobnie jak i w innych językach) w różnych kontekstach znaczeniowych.

Kultura (lac. colere - uprawiać, dbać, pielęgnować, ksztalcenie/uprawa) pochodzi od lacińskiego cultus agri (dokładnie „uprawa roli”), później używanego w znaczeniu cultura animi („uprawa umyshu”) (Golka 2008: 32-33). Trudno znaleźć pojęcie szersze znaczeniowo: „Nie ma nic bardziej nieokreślonego niż słowo kultura i nic bardziej zwodniczego, jak stosowanie go do calych ludów i cały ch epok", pisał niemiecki filozof Johann Gottfried Herder (1962: 4). W konsekwencji jest to termin wieloznaczny, interpretowany w wieloraki sposób przez przedstawicieli różnych nauk (archeologów, etnografów, antropologów, psychologów, socjologów, kulturoznawców). Filozof Jerzy Kosiewicz (2004: 67) ustalit, że istnieje ponad 200 różnych definicji kultury stosowanych w akademickich dyscyplinach kulturoznawczych. Zakres pojęcia jest niezwykle szeroki i poszczególne ujęcia mogą eksponować różne elementy w zależności od przyjętej perspektywy: istnieją definicje zorientowane praktycznie, te o proweniencji antropologicznej, te nawiązujące do behawioralnego punktu widzenia, te opisowo-wyliczające (nominalistyczne). W konsekwencji kultura może być rozpatrywana jako forma świadomości spolecznej, jako sfera wartości symbolicznych, w wymiarze materialnym (jako ogól wytworów ludzi) albo niematerialnym: duchowym i symbolicznym (wzory myślenia i zachowania). Istnieją ujęcia traktujące kulturę atrybutywnie lub dystrybutywnie, szeroko lub wąsko (sensu largo lub stricto), opisujące kulturę w rozumieniu wartościującym lub opisowym, co odzwierciedlają dwa przymiotniki: kulturalny — kulturowy (Golka 2008: 43). Nie sposób wyliczyć i przywolać wszystkich definicji i ich twórców. W kontekście późniejszych rozważań dotyczących zastosowania i rozumienia terminu kultura w teorii kultury fizycznej warto jednak przytoczyć definicję kultury (jedną z wielu tej samej autorki) wybitnej polskiej socjolog Antoniny Kloskowskiej, eksponującą antropologiczny, socjocentryczny i behawioralny punkt widzenia: , , $[.$.$] kultura jest to względnie zintegrowana$ 
calość obejmująca zachowania ludzi, przebiegające według wspólnych dla zbiorowości spolecznej wzorów wyksztalconych w toku interakcji, oraz zawierająca wytwory takich zachowań" (Kloskowska 1981: 40). Powszechnie spotykane zestawienia (rozumiane jako jednostka leksykalna) z terminem ,kultura” to: kultura ludowa, kultura masowa, kultura narodowa, kultura elitarna, kultura popularna, kultura regionalna, kultura lokalna, kultura polityczna, kultura języka, kultura organizacyjna, kultura materialna, kultura duchowa, kultura spoleczna, a także kultura fizyczna.

Przydawka przymiotna ,fizyczna” wywodzi się od greckiego słowa physis (gr. pviøı). Termin ten jest najczęściej thumaczony jako „natura” (może także oznaczać naturalny rozwój lub ewolucję występującą w przyrodzie), a zatem w konsekwencji „fizyczny" jest określeniem synonimicznym do „naturalny”. W uzusie językowym przymiotnik „fizyczny" ma kilka podstawowych znaczeń. Po pierwsze, dotyczy fizyki (jako nauki) i zjawisk, którymi ona się zajmuje, również przyrody i uksztaltowania skorupy ziemskiej. Po drugie, odnosi się do wyglaadu zewnętrznego człowieka i organizmu czlowieka. Po trzecie, może oznaczać „seksualny” oraz „dostępny zmysłom”. Wreszcie istnieje znaczenie podkreślające wykonywanie pracy wymagającej sily mięśni („oparty na sile mięśni”) oraz dotyczy „wyrobienia sportowego" (Slownik języka polskiego PWN 2007). Powszechnie używane wyrażenia z przymiotnikiem ,fizyczny" to: geografia fizyczna, praca fizyczna, kontakt fizyczny, ból fizyczny, pociag fizyczny, czas fizyczny, objawy fizyczne, a także kultura fizyczna.

Można zauważyć, że powstałe zestawienie, $\mathrm{z}$ językoznawczego punktu widzenia, jest zatem niejako oksymoronem - sklada się z rzeczownika i epitetu sprzecznego (przymiotnika o przeciwstawnym znaczeniu). Innymi slowy: dwa czlony wykluczają się wzajemnie, podobnie jak: „żywy trup", ,sucha woda”, „pracowite lenistwo”, ,gorzkie szczęście". Warto jednak przypomnieć, że wiele antylogii wchodzi do powszechnego uźycia, tracąc swoje pierwotnie paradoksalne, sprzeczne znaczenie. Takimi wyrażeniami są, np.: „,wirtualna rzeczywistość”, „suchy lód”, „wymowne milczenie” czy „,zimne ognie”. W tym kontekście nie szokuje zestawienie kultury (cywilizacji, dziedzictwa) z fizycznością (naturą). Dalej, nawiązując do rozważań Ireneusza Bittnera (1995: 95-96), moz̀na stwierdzić, że kultura fizyczna stanowi w sensie pojęciowym jedność merytoryczną, choć ma - tak jak moneta - dwie różne strony: awers o charakterze humanistycznym i rewers o właściwościach praktycznych.

\section{HISTORIA POJECIA KULTURA FIZYCZNA}

Kosiewicz (2004: 66) zauważa, że chociaż etymologia czy historia terminu kultura fizyczna sięga starożytności, to jednak zastosowanie tego pojęcia spopularyzowało się szerzej dopiero w XX w. i trafiło do języka potocznego, czego rezultatem są zniekształcenie sensu, nieporozumienia, sprzeczne oceny, wieloznaczność pojęcia, różnorodne możliwości interpretacji oraz niekiedy wręcz kontradyktoryjność znaczeń (co zostanie szczególowo omówione w dalszej części artykułu). Na tym etapie rodzi się pytanie o przyczynę takiego stanu rzeczy. Konieczne wydaje się zatem prześledzenie 
losów tego pojęcia ze wskazaniem na geograficzne, historyczne i spoleczne uwarunkowania użycia tego terminu.

Według dostępnych źródeł określenie kultura fizyczna pojawilo się w piśmiennictwie po raz pierwszy w przestrzeni anglojęzy cznej w roku 1899, a konkretnie w Stanach Zjednoczonych (Piątkowska 2006: 83). W marcu tamtego roku ukazal się pierwszy numer czasopisma Physical Culture (Kultura Fizyczna), wydawanego w Stanach Zjednoczonych, w języku angielskim, przez Bernarra Macfaddena (1968-1955), amerykańskiego propagatora aktywności ruchowej. Czasopismo poświęcone było tematyce zdrowia, fitness i rozwoju fizycznego. W 1941 r. dodano podtytul Beauty and Health (Piękno i Zdrowie); w 1944 zmieniono tytul na New Physical Culture (Nowa Kultura Fizyczna), porzucając podtytuł, a w $1950 \mathrm{r}$. czasopismo zaczęlo się ukazywać pod nowym tytułem:Macfadden's Health Review (Przeglad.Zdrowotny Macfaddena) (http://www.magazineart.org/main. $\mathrm{php} / \mathrm{v} /$ healthandfitness/physicalculture/). Physical Culture bylo zreszta jednym z wielu magazynów (o przeróżnych profilach) ukazujących się za sprawą wydawnictwa Macfadden Publications, zalożonego przez samego Macfaddena; warto dodać, że równolegle istniało także czasopismo zatytulowane Sport. W opinii znawców tematyki (Wharton 1982: 297; Griffith 2000; Mrozek 1987; Todd 1987) Macfadden odegral glówną rolę w promocji kultury fizycznej w Ameryce, co wynikalo z umiejętnego polączenia jego osobistych zainteresowań i przekonań z chęcią zysku. Można również dodać, że przyczynil się w znacznym stopniu do rozpowszechnienia samej nazwy. Przeszedl przecież bowiem do historii jako autor licznych publikacji poświęconych kulturze fizycznej i zdrowiu (m.in. 8-tomowej encyklopedii kultury fizycznej Macfadden's Encyclopedia of Physical Culture, której nakład wielokrotnie wznawiano²), założyciel nowojorskiej restauracji Physical Culture z kartą dań opartą na potrawach wegetariańskich i szkól treningowych kultury fizycznej healthatoriums, a takżejako fanatyk diet, zagorzaly zwolennik salutogennych glodówek i poszczenia w imię odnowy biologicznej, miłośnik body-building oraz proz-

\footnotetext{
${ }^{2}$ Warto wymienić tytuly książek zawierające w tytule termin kultura fizyczna, a zatem: Physical Culture for Babies (1904), wspomniana Macfadden's Encyclopedia of Physical Culture (1911-1912; wielokrotnie wznawiana), Physical Culture Cook Book (1924), choć należy pamiętać, iż duch pojęcia kultury fizycznej obecny byl w licznych poradnikach dotyczących diety, zdrowego trybu życia, zwalczania chorób i dolegliwości, dążenia do piękna i doskonalenia sprawności fizycznej: Physical Training (1900), Fasting, Hydropathy, and Exercise (1900), Power and Beauty of Superb Womanhood (1901), Strength from Eating (1901), Strong Eyes (1901), Natural Cure for Rupture (1902), Building of Lital Power (1904), Health, Beauty, and Sexuality (1904), How Success Is Won (1904), A Perfect Beauty (1904), Muscular Power and Beauty (1906), Vitality Supreme (1915), Brain Energy (1916), Making Old Bodies Young (1919), Truth About Tobacco (1921), The Miracle of Milk (1923), Fasting for Health (1923), Constipation: Its Cause, Effect, and Treatment (1924), How To Raise a Strong Baby (1924), Walking Cure, Pep and Power from Walking - How to Cure Disease (1924), Hain Culture (1921), Diabetes: Its Cause, Nature and Treatment (1925), Headaches: How Caused and How Cured (1925), Strengthening the Spine (1925), Tooth Troubles (1925), Asthma and Hay Fever. (1926), Colds, Coughs, and Catarrh (1926), Foot Troubles (1926), Rheumatism, Its Cause, Nature and Treatment (1926), Skin Troubles (1927), Digestive Troubles (1928), Talks to a Young Man about Sex (1928), Tuberculosis (1929), Home Health Manual (1930), After 40 - What? (1935), Woman's Sex Life (1935), How to Gain Weight (1936), How to Reduce Weight (1936), Be Married and like It (1937). Lącznie Macfadden był autorem ponad stu książek.
} 
drowotnej aktywności seksualnej. W istocie: choć zdobył reputację za propagowanie kultury fizy cznej i sprawności, prawdziwy rozglos zy skal za swoje niety powe poglądy na temat ascezy żywieniowej i prozdrowotnych zachowań seksualnych. Ta wszechstronna, wieloogniskowa działalność przyniosła mu fortunę oraz przydomki, takiejak „,muskularny milioner”, „Body Love Macfadden” (Macfadden kochający cialo), „kook” (w slangu: dziwak/wariat) oraz „szarlatan” (Adams 2009; Ernst 1991; Wood 2003).

Termin dotarł niedługo później także na Stary Kontynent i znaleźć go można w tytułach różnych publikacji. W Polsce musial się pojawić bardzo szybko i byl powszechnie używany na poczatku XX w. Na lamach warszawskiego dwutygodnika Ruch w $1908 \mathrm{r}$. opublikowano pod redakcją Wladysława Kozłowskiego np. artykuł zatytulowany Kultura fizyczna a prasa codzienna - pojęcie musialo być zatem zrozumiale dla ówczesnych czytelników (Piątkowska 2006: 83). Slynne dzielo G.A. Duperrona, uważane za pierwszy podręcznik z zakresu kultury fizycznej, zostało wydane w $1925 \mathrm{r}$. w Moskwie. Należy przypomnieć, że mimo oficjalnej przynależności do „bloku wschodniego” autor był od 1913 r. czlonkiem Międzynarodowego Komitetu Olimpijskiego (Piątkowska 2006: 84), co oznacza, że miał styczność z ,zachodnim" środowiskiem, pozostawal pod jego wplywem i m.in. tam ksztaltowaly się jego światopogląd oraz - silą rzeczy slownictwo. Terminu kultura fizyczna używali także polscy teoretycy, m.in. Eugeniusz Piasecki, i byly pięściarz — dziennikarz Wiktor Junosza-Dąbrowski. Ten drugi w 1933 r. zatytulowal swoją książkę Podstawy ideowe kultury fizycznej (Godlewski 2005: 522). Mimo iż nieobca byla mu koncepcja kultury fizycznej w ZSRR (omawiając kwestie przysposobienia wojskowego, odwoluje się do „Sowietów”), nie łączył on jednak tego pojęcia bezpośrednio z systemem ideologiczno-organizacyjnym, w takim wymiarze, jak robią to późniejsi autorzy.

Termin kultura fizyczna musial być też dosyć powszechnie używany w krajach anglojęzycznych, o czym świadczy jego obecność w licznych dziełach leksykograficznych, np. w słowniku autorstwa Herberta Haaga, Filipa Messa i Geralda Haaga (2012: 186) oraz w leksykonic wydanym w 1974 r. z inicjatywy Międzynarodowej Rady Wychowania Fizycznego i Sportu (Conseil International pour l'Education Physicque et le Sport) dzialającej pod patronatem UNESCO. Odnosil się przy tym przede wszystkim do narodowych systemów gimnastycznych promowanych w XIX w. w Szwecji przez Pehra Henrika i Hialmara Lingów, a w Niemczech przez Friedricha Ludwiga Jahna (gimnastyka sportowa i kalistenika) w ramach holistycznego treningu prozdrowotnego $\mathrm{i}$ wojskowego. Systemy te wywieraly ogromny wplyw na dzialania edukacyjne i militarne, i nolens volens naznaczyly, czy obarczyly, pojęcie kultury fizycznej. W rezultacie pojęcie to przestalo określać „zwyklą" aktywność fizyczną i zaczęlo powoli znikać z powszechnego użycia. A nawet więcej. Zaczęlo dryfować w jeszcze mocniej zaakcentowanym kierunku politycznym, zwłaszcza że termin ten szczególnie upodobali sobie po drugiej

\footnotetext{
${ }^{3} \mathrm{~W}$ dalszej części artykulu przytacza się dokladną tres̉ć definicji zawartej w tym slowniku, noszącym notabene tytul - co ciekawe i zaskakujące: Sport. Physical Education. Sport Sciences, mimo iż w haśle kultura fizyczna mówi się o nadrzędności tego właśnie terminu.
} 
wojnie światowej politycy krajów socjalistycznych. Piotr Godlewski słusznie zauważa, że ,[...] w warstwie pojęciowej nad terminem kultura fizyczna ciąży spuścizna czasów stalinizmu" (2005: 520). Tam, gdzie rządzili komuniści, to, co uważa się za wychowanie fizyczne i sport, nazywano kulturą fizyczną. Wiadomo także, jak wielką rolę odgrywała wlaśnie kultura fizyczna w systemie politycznym, jakim jest narodowy socjalizm: kultura fizyczna stanowila integralną częśc kultury państw bloku wschodniego i jako taka byla przedmiotem szczególnej opieki partii. Poprzez wychowanie fizyczne naród mial się stać silny i zdrowy. Nie chodzilo jednak o dobro jednostek, lecz o zadania polityczne, tj. o pracę na rzecz państwa. W sporcie wyczynowym ważne było ukazanie wyższości ustrojowej kraju i systemu, a nie dążenie do doskonalości sportowca i ruchu. W tym kontekście warto przytoczyć opis znaczenia kultury fizycznej w krajach totalitarnych socjologa Krzysztofa Jankowskiego:

System kultury fizycznej, podobnie jak inne systemy i instytucje społeczne, podporządkowany jest państwu, a jego zadaniem jest realizacja celów przede wszystkim o charakterze instrumentalnym. Jak się wydaje, do najważniejszych cech, jakie należałoby wyróżnić, można zaliczyć: wykorzystanie kultury fizycznej a zwlaszcza sportu jako narzędzia oddziaływań propagandowych. Sukcesy mają w przekonaniu rządzących udowodnić wyższość jednego systemu politycznego nad innymi lub świadczyć o dominacji własnej nacji. Po wtóre ukierunkowanie edukacji fizycznej, zwłaszcza ludzi młodych, na powszechną militaryzację społeczeństwa, i wreszcie wykorzystanie kultury fizycznej do sterowania nastrojami mas (np. pokazy gimnastyczne na stadionach z tysiącami uczestników itp.) (Jankowski 2011: 292).

Wobec powyższego naleźy zdać sobie sprawę, że przez ponad pół wieku wychowanie fizyczne i sport, nazywane „kulturą fizyczną", poddawane były w Europie Wschodniej rządzonej przez komunistów intensywnej indoktrynacji. Sport w państwach tzw. obozu socjalistycznego zostal calkowicie znacjonalizowany. W założeniu mial służyć nie tylko jednostkom, lecz przede wszystkim spoleczeństwu, a więc socjalistycznemu państwu. Tak było notabene również w innych dziedzinach życia: dobro spoleczne (państwa, ogólu, wszystkich) traktowano ponadjednostkowo. W rzeczywistości wychowanie fizyczne i sport wykorzystywano do celów komunistycznej propagandy. Termin ten wszedl do oficjalnej frazeologii państwowej administracji sportowej, ochoczo przejęli go też marksistowscy ideolodzy sportu i wychowania fizycznego z wyższych szkól o profilu sportowym i bez większych oporów przyjął się on w ruchu sportowym (Godlewski 2005: 520-521). Przyjęty w latach 40. ubieglego wieku system organizacyjny funkcjonuje w pewnym sensie i w niektórych kręgach do dziś. Stąd też, jak zauważa Lech Jaczynowski (2000: 30), wielu naukowców uważa, że termin kultura fizyczna wywodzi się wręcz pierwotnie z języka rosyjskiego i stąd niechęć czy świadoma rezygnacja $z$ tego pojęcia. Niewątpliwie okres skrajnie lewicowego oddzialywania odcisnąl piętno na sformulowaniu kultura fizyczna i dlatego przylgnęla do niego bardzo mocno (czy wręcz zbyt silnie) ta ,niewygodna etykieta". Zaryzykujmy dobitne stwierdzenie: blok wschodni „obrzydzil” ten termin spoleczeństwu zachodnioeuropejskiemu, wykazującemu nieskrywaną niechęć do komunizmu i wszystkich modeli socjalistycznych. Co jednak ciekawe, wydaje się, że to przede wszystkich Europa Zachodnia broni się przed 
wykorzystywaniem tego pojęcia, podczas gdy jest ono używane w anglojęzycznych krajach - Australii, Kanadzie i Stanach Zjednoczonych. Do takiego wniosku dochodzi m.in. Monika Piątkowska (2006), która bacznie się przyjrzała losowi pojęcia kultura fizyczna, próbując ustalić jego rozumienie i funkcjonowanie na świecie (w wybranych państwach i językach), podając „pobudki polityczne” jako jedną z możliwych przyczyn odejścia od niego w krajach Europy Zachodniej.

Przyjrzyjmy się jeszcze dokładniej — w perspektywie diachronicznej — sytuacji w naszym kraju. W Polsce sam termin występowal, jak wcześniej wspomniano, już na poczatku XX w. i do drugiej wojny światowej nie byl kojarzony z jakimś konkretnym systemem ideowo-organizacyjnym. W uchwale II Zjazdu Komunistycznej Partii Polski z sierpnia 1923 r. nie pojawia się jeszcze sformulowanie kultura fizyczna, mowa jest jedynie o potrzebie podjęcia energicznej pracy w dziedzinie ruchu sportowego (Godlewski 2005: 522). Ideologiczne znaczenie kultury fizycznej wprowadzono w Polsce dopiero po 1945 r., przy czym pierwsze interpretacje były raczej oszczędne w akcenty polityczne i założenia doktrynalne. $Z$ czasem jednak system centralnego zarządzania narzucony przez komunistów przyjąl się na gruncie polskim i obejmowal stopniowo wszystkie dziedziny życia spolecznego, a zatem także wychowanie fizyczne i sport wyczynowy. Jak ustala Jerzy Urniaż (2015: 17), pojęcie kultury fizycznej szczególnie zyskało na popularności pod koniec pierwszej połowy XX w., co ma związek z uchwala Biura Politycznego Komitetu Centralnego PZPR z 28 września 1949 r. w sprawie kultury fizy cznej i sportu. Wprowadzono wówczas system oparty na wzorach radzieckich, który zrywał z koncepcją działalności sportowej z okresu II Rzeczypospolitej, a wychowanie fizy czne i sport od tego czasu staly się istotnymi skladowymi kultury fizycznej. Wytyczną dla nowego modelu stanowily pryncypia ideowe, m.in. powszechność i ludowość, co mialo sprzyjać rozwojowi i sprawności fizycznej mlodzieży, pracy i obronie państwa oraz wspierać rozwój sportu wyczynowego, od sportowców oczekiwano zaś wysokich wyników w rywalizacji międzynarodowej. Kultura fizyczna miała być środkiem do psychofizycznej przebudowy czlowieka, do wychowania typu nowego obywatela: zawodowo-fachowego, politycznie uświadomionego, twórczego, spolecznie wy robionego, zdecydowanego, wiernego systemowi. Chodzilo nie tylko o praktyczne wdrożenie tego projektu, lecz także o jego odpowiednią obudowę językową — stąd konieczne było przyjęcie nowej nomenklatury i sformułowanie nośnych haseł do propagandowego stosowania w powszechnym obiegu. W Polsce została w $1950 \mathrm{r}$. ustanowiona odznaka „Sprawny do Pracy i Obrony" (SPO), która w samej nazwie zawierala cechy pożądane u obywatela. Z wy soką rangą kultury fizycznej i sportu na niespotykaną dotąd w Polsce skalę lączyla się potrzeba rozwoju uczelni i szkól wychowania fizycznego, których zadaniem byla troska o zabezpieczenie kadr nauczycielskich i prowadzenie badan naukowych w tej dziedzinie (Gaj, Hądzelek 1991; Szymański 2004). Kultura fizyczna stała się narodową i społeczną wartością, zaakceptowaną i zdefiniowaną, stanowiąc istotny element kultury spolecznej. Zajmowala się ksztaltowaniem fizycznych uzdolnień czlowieka podczas zajęć wychowania fizycznego i w sporcie, a także higieną osobistą i organizacją czynnego wypoczynku oraz stosowną do tego nauką. Do 1989 r. pojęcie 
kultura fizyczna, w warstwie praktycznej i teoretycznej, bylo powszechnie uznawane i rozpoznawalne nie tylko w środowisku naukowym, lecz także w spoleczności ,laików" (pozauczelnianej). Jednocześnie pochodzenie i rozumienie źródeł tożsamości kultury fizycznej nie budzilo wątpliwości. Wśród ogromnej większości pracowników dydaktyczno-naukowych uczelni wychowania fizycznego kultura fizyczna tworzyla wlasną naukę, niezależnie od występującej w niej różnorodności. Dawalo to poczucie wartości i naukowości w stosunku do innych dziedzin i nauk, i takiego postrzegania i rozumienia kultury fizycznej nie zmienila transformacja ustrojowa, mimo tworzenia politycznego klimatu pozbycia się pojęcia kultury fizycznej jako obcego i wrogiego oraz chęci zastąpienia go terminem „sport” (Urniaż 2015: 17). Przyjęta w połowie lat 40. terminologia utrwalila się w działalności naukowej, w dokumentach władzy ustawodawczej i wykonawczej. Rozpoczęta w 1989 r. transformacja polityczna i spoleczna (obecna i zauważalna także w sporcie i w innych komponentach systemu kultury fizycznej) przełamuje powoli, aczkolwiek z dużymi oporami, marksistowski model organizacji spraw sportu wyczynowego, masowego (powszechnego) oraz szkolnego (wychowania fizycznego). Doskonale podsumowuje to Godlewski:

Kilkanaście lat deklaratywnej dezintegracji systemu socjalistycznej kultury fizycznej nie oznacza pełnego odrzucenia marksistowskiej koncepcji „kultury fizycznej”, mimo iż stała się ona amorficzna — istniejąca terminologia nie dla wszystkich jest eklektyczna — nadal mamy ustawę o „kulturze fizycznej” (faktycznie to ustawa o wychowaniu fizycznym i sporcie; [...] rekreacji i rehabilitacji poświęcono zaledwie dwa artykuly: 42 i 43) (Godlewski 2005: 526).

Nie ulega wątpliwości, iż od początku lat 90 . zaszly w życiu polityczno-spoleczno-gospodarczym olbrzymie zmiany i objęly one także sektor sportowy. Język, będący odzwierciedleniem sposobu myślenia i pamięci ludzkiej, ,zapomina”.jednakże wolniej: cała frazeologia wokól hasła kultura fizyczna zgodna była z ideologicznymi i politycznymi założeniami państwa zarówno w okresie stalinizacji, jak i później w tzw. realnym socjalizmie i termin ten nadal kojarzy się z doktryną polityczną z okresu przed transformacją i z zasadą centralnego sterowania typową dla krajów socjalistycznych. Proces „zapomnieniajęzykowego" jest zawsze dlugotrwaly. Zwlaszcza że równolegle toczy się inne postępowanie obowiązujące przede wszystkim w zakresie nomenklatury władzy ustawodawczej i wykonawczej. Pod wplywem tendencji do unifikacji w ramach Unii Europejskiej rozpoczyna się odgórny proces modernizacji terminologii: w nazwach ministerstwa, stowarzyszeń i federacji króluje słowo sport (zob. tabela 3). Nowo tworzone organizacje i projekty ustaw unikają terminu kultura fizyczna, znika on również z innych rządowych dokumentów i oficjalnej retoryki.

Podsumowując rozważania o historii terminu, można powiedzieć, że mamy do czynienia ze stosunkowo „młodym”, nieco ponadstuletnim, pojęciem o „zacnej genezie” i „trudnych losach". Obecne komplikacje i niejasności w nomenklaturze są spowodowane tym, iż (najprawdopodobniej) termin ten zostal użyty po raz pierwszy w środowisku amerykańskim (neutralnie i zgodnie z etymologicznymi przesłankami), później został - wciąz prawidłowo - wykorzystany do opisu systemów dbałości o rozwój 
motoryczny, cialo i zdrowie w Niemczech i Szwecji, a następnie przylgnąl do pewnych praktyk typowych dla ustroju socjalistycznego i posilkowala się nim marksistowska ideologia. System komunistyczny w pewnym sensie wypaczył początkowe znaczenie terminu, uwikłał go w politykę, naznaczył go „na czerwono”, ściąnąl lawinę krytyki i tym samym doprowadzil do pewnego znienawidzenia go i stopniowej, aczkolwiek systematycznej i świadomej rezygnacji z niego. Wlaśnie ze względu na tę przylepioną etykietę polityczną i negatywną konotację pojęcie to jest obecnie niezrozumiale lub niewłaściwie interpretowane.

\section{ZNACZENIE I ZAKRES POJĘCIA KULTURA FIZYCZNA I TERMINÓW KONKURENCYJNYCH}

Pojęcie kultura fizyczna jest związane, jak zauważa Kosiewicz, „,[..] z wielością, różnorodnością i zmiennością zjawisk natury społecznej, podmiotowej i przyrodniczej, dotyczącej humanizacji przyrody" (Kosiewicz 2004: 66). Jeśli przypomnieć, jak wiele trudności przysporzyło zbudowanie definicji kultury, to nie ma się co dziwić, że także definicja kultury fizycznej może budzić kontrowersje. Przydawka przymiotna z jednej strony specyfikuje i zawęża zakres pojęcia, a z drugiej stanowi nawiązanie do innej sfery i lączy je z przestrzenią fizyczności i natury. W tym pojęciu mieści się zatem ta częśc kultury, która związana jest z rozwojem psychofizycznym (a zatem zarówno zewnętrznym - biologicznym, somatycznym, jak również wewnętrznym - duchowym, psychicznym) czlowieka, dbałością o zdrowie, poprawną postawę, sprawność, wydolność fizyczną oraz piękno ruchu i ciała. Warto przywołać na początku definicje kultury fizycznej z ogólnych, tj. niespecjalistycznych, slowników. W pierwszym powojennym Slowniku języka polskiego, pod redakcją Witolda Doroszewskiego, znajdziemy wyjaśnienie, że kultura fizyczna to uprawianie sportu i sprawność fizyczna osiagnięta dzięki uprawianiu sportu, a wjednym z najnowszych dzieł leksykograficznych, Uniwersalnym słowniku języka polskiego pod redakcją Stanisława Dubisza, czytamy, że to dziedzina obejmująca naukę o wychowaniu fizycznym, sport, higienę osobistą oraz racjonalną org anizację czynnego wypoczynku. Warto zaznaczyć, że nie odnotowuje takiego związku kognitywny Inny slownik języka polskiego pod redakcją Mirosława Bańki.

Dokładniejsze definicje kultury fizycznej znajdziemy w dziełach specjalistycznych. Niewątpliwie poprawne i precyzyjne są te, w których uwypukla się znaczenie systemu wartości, światopoglądu, przekonań i postaw (co podkreśla Maciej Demel), a także tradycji (dorobku spolecznego) oraz indywidualnych i spolecznych potrzeb jednostek (co akcentuje Andrzej Wohl); udaną syntezą jest również definicja zawarta w ustawie o kulturze fizycznej z 1996 r.:

Kultura fizyczna obejmuje te wszystkie wartości, które wiążą się z fizyczną postacią i fizycznym funkcjonowaniem człowieka, zarówno w jego wlasnym subiektywnym odczuciu, jak też w obrazie społecznie zobiektywizowanym. Analogicznie do innych wartości kulturowych mają one charakter dynamiczny, ksztaltują poglądy i postawy ludzkie (Demel 1974: 215). 
Kultura fizyczna to całoksztalt dorobku spolecznego $\mathrm{w}$ dziedzinie pielęgnacji ciala, to jest całoksztalt systematycznie stosowanych środków natury sprawnościowej, wychowawczej, higienicznej i rozrywkowej, wpływających na rozwój fizyczny ludzi, rozwój ich aparatu ruchowego oraz przystosowanie tegoż aparatu do wszechstronnych potrzeb osobowości ludzkiej w danych warunkach rozwoju życia społecznego (Wohl 1974: 219).

Kulturą fizyczną jest wiedza, wartości, zwyczaje, dzialania podejmowane dla zapewnienia rozwoju psychofizycznego, wychowania, doskonalenia uzdolnień i sprawności fizycznej czlowieka, a także dla zachowania oraz przywracania jego zdrowia (Ustawa z dnia 18 stycznia 1996 r. o kulturze fizycznej, Dz.U. 1996, nr 25, poz. 113, rozdz. 1 art. 1).

Warto też przytoczyć pewną zagraniczną definicję kultury fizycznej, pochodzącą z uznanego międzynarodowo dziela, jakim jest slownik Dictionary. Sport - Physical Education - Sport Science (w tytule nie ma mowy o kulturze fizycznej!) autorstwa Herberta Haaga, Filipa Messa i Geralda Haaga:

Physical culture - originally term for the image of the life reform movement around the turn ofithe century in Germany, with efforts towards holistic care and improvement of human health and performance capacity and therefore of the entire human being (the term is still contained in free body culture, which represents optional dress bathing, i.e. going to nude beaches). As a component of the socialist working culture, the term was picked up by the Arbeiter-, Turn- und Sportbewegung (Workers', Gymnastics and Sport Movement) and is today the most comprehensive term for sport and physical exercises; it was part of the national culture in (former) socialist countries (Haag, Mess, Haag 2012: 186).

Istnieje oczywiście jeszcze wiele innych, bardziej lub mniej udanych, szerszych lub węższych, starszych lub nowszych definicji kultury fizycznej i nie sposób przywolać tu ich wszystkich. Przegląd ten zamkniemy ujęciem Zbigniewa Krawczyka, zgodnie z zapowiedzią socjolog oparł się na przywoływanej wcześniej definicji kultury Kłoskowskiej, eksponującej antropologiczny, socjocentryczny i behawioralny punkt widzenia, pozostawiając takie samo rozlożenic akcentów:

Kultura fizyczna to względnie zintegrowany i utrwalony system zachowań w dziedzinie dbałości o rozwój fizyczny, sprawność ruchową, zdrowie, urodę, fizyczną doskonalość i ekspresję czlowieka, przebiegających według przyjętych w danej zbiorowości wzorów, a także rezultaty owych zachowań. Jako taka wiąże się ona integralnie ze zjawiskami wychowania, higieny osobistej i spolecznej, pracy i wypoczynku oraz dążeniem do poprawy materialnych i psychicznych warunków ludzkiego bytowania (Krawczyk 1983: 11).

Jest to definicja bardzo obszerna, uznawana za najbardziej odpowiednią i reprezentatywna, chyba także najczęściej cytowana, ale nawet ona nie uniknẹła słów krytyki: zdaniem Kosiewicza (2004: 69) jest zbyt redukcjonistyczna i niewystarczająco eksponuje wartości duchowe współdziałające w tworzeniu przejawów kultury fizycznej (nie tylko cielesnej, ale także materialnej). Żeby nie wdawać się w dyskusję nad zasadnością tego zarzutu, można zaakcentować różnorodność, wieloznaczność i wieloaspektowość pojęcia kultury fizycznej, przekladające się na interdyscyplinarność i multidyscyplinar- 
ność w prowadzeniu badań, i skłonić się ku opisowo-wyliczającym ujęciom. Krawczyk wymienia cztery typy (rodzaje) rozumienia kultury fizycznej:

— jako całoksztalt materialnego środowiska, ksztaltowanego przez człowieka zgodnie z jego możliwościami, potrzebami i wartościami,

— jako system wartości, dzialań oraz ich efektów w dziedzinie cielesnej aktywności czlowieka, zależnych od zewnętrznych warunków i stymulowanych przez spoleczne potrzeby,

— jako zespół form aktywności ruchowej człowieka, podejmowanych świadomie i celowo dla pomnażania zdrowia, rozwoju sprawności fizycznej i urody człowieka, podporządkowanych wzorowi osobowości wszechstronnej, harmonijnej i dynamicznej,

- jako synonim sportu, przy czym użycie to nie jest typowe dla Polski i innych krajów Europy Srodkowej i Wschodniej (Krawczyk 1997: 11-12).

To ostatnie rozumienie zdaje się zyskiwać w ostatnim czasie na popularności, także niestety w Polsce, $i$,,sport" dołącza tym samym do grupy — chciałoby się powiedzieć konkurencyjnych wobec kultury fizycznej pojęć, które pozostają niewątpliwie we wzajemnej relacji i są terminami bliskoznacznymi, podobnie interpretowanymi w pewnych kontekstach, lub hiponimicznymi, ale nie synonimicznymi (tożsamymi), gdyż zakres ich znaczenia nie jest identyczny. Bardziej nośnego i mocno propagowanego pojęcia sport nie sposób jednakże utożsamiać z poznawczo dużo szerszym i kulturowo pełniejszym określeniem kultura fizyczna. Jak podkreśla Urniaż, ,.[...] termin sport nie może uogólniać całej kultury fizycznej, chociażby z racji widocznych paradygmatów oraz różnic systemowych i aksjologicznych wnoszonych w życie społeczne. Można nawet uznać, że kultura fizyczna pelni tu rolę nadrzędną" (Urniaż 2015: 21). Sport to przecież, na równi z wychowaniem fizycznym, rehabilitacją ruchową, rekreacją i turystyką, tylko jeden z elementów tworzących kulturę fizyczną. Niewątpliwie, porównując z innymi elementami, sport wyczynowy jest najbardziej spektakularny, widoczny (medialnie i ogólnospołecznie), dynamicznic rozwija się i pochlania olbrzymie środki finansowe, przekładające się na zwielokrotnioną i wzmocnioną obecność w przestrzeni spolecznej. Jak zauważa Krawczyk: ,[...] jest rzeczą charakterystyczną, że ten ostatni [,wielki" sport - J.M.] ze względu na swoje walory widowiskowe i międzynarodowy zasięg jest wyją̧kowo ekspansywny, dlatego też często pojmowany jest jako synonim sportu w ogóle" (Krawczyk 2011: 28). Niemniej jednak olbrzymia popularność i funkcjonowanie w świadomości spolecznej w żaden sposób nie uprawniają do rezygnacji z hiperonimicznego pojęcia kultura fizyczna i redukcji do hiponimu — z zalożenia podrzędnego i obejmującego tylko część zakresu. Mialoby to bowiem poważne, zubażające kulturę (sensu largo) konsekwencje.

Innym konkurencyjnym, bliskoznacznym pojecciem jest kultura somatyczna (wywodzące się z greckiego somatikós od sóma, -atos 'cialo'), oznaczające kulturę cielesną (a także fizyczną). Używanie tego terminu zamiennie z pojęciem kultura fizyczna (praktykowane przez cześć przedstawicieli nauk o kulturze fizycznej) jest uzasadnione tylko w niektórych kontekstach, gdyż pojęcia te - etymologicznie - mają różniące się 
zakresy,jedynie w pewnej części krzyżujące się i zachodzące na siebie (Kosiewicz 2004: 72-73). Niewątpliwie definicja kultury somatycznej i definicja kultury fizycznej mają wspólne merytoryczne pole zainteresowań, dotyczace zachowań w dziedzinie dbałości o rozwój fizyczny, sprawność ruchową, zdrowie i fizyczną doskonałość czlowieka, ale różni je to, iż kultura somatyczna bierze pod uwagę czysto biologiczną naturę czlowieka, kultura fizyczna natomiast zajmuje się poza dbalością o rozwój fizyczny również innymi przejawami aktywności czlowieka w sferze - ujmijmy to - kulturowej (artystycznej, materialnej i instytucjonalnej). Należy dodać na marginesie, że dodatkowo sytuację terminologiczną komplikuje obecność w fachowej (głównie antropologicznej) literaturze przedmiotu pojęcia kultura ciała wprowadzonego na początku XX w. dla oznaczenia pewnych alternatywnych form fizycznych praktyk, mających na celu powrót do naturalnego trybu ży cia z ukierunkowaniem na nowe aktywności ciala, m.in. nudyzm, rytmicznie-ekspresyjna gimnastyka, ruch na świeżym powietrzu, budowanie ciala (Wedemeyer-Kolwe 2004). Termin ten pojawia się jako pewien kompleks znaczeniowy (choć zróżnicowany i różnie interpretowany) w różnych językach: w angielskim — body culture (Eichberg 1998; Bale 2002), w niemieckim - Korperkultur (Eichberg, Hansen (red.) 1989; Wedemeyer-Kolwe 2004), we francuskim - culture de corps (Mauss 1973), w dunskim — kropskultur (Korsgaard 1982; Nielsen 1993; Vestergard Madsen 2003), w fińskim - ruumiinkulttuuri (Sironen 1995).

\begin{tabular}{|c|c|}
\hline Kultura som atyczna & Kultura fizyczna \\
\hline — opiera się na greckim pojęciu soma (ciało) & — opiera się na greckim pojęciu physis (natura) \\
\hline $\begin{array}{l}\text { - odnosi się do ciała ludzkiego jako faktu natu- } \\
\text { ralnego (biologicznego) }\end{array}$ & $\begin{array}{l}\text { - odnosi się do ciała ludzkiego jako faktu kultu- } \\
\text { rowego i naturalnego }\end{array}$ \\
\hline $\begin{array}{l}\text { - obejmuje caloksztalt zjawisk cielesnych (w tym } \\
\text { fizjologiczne czynności ruchowe poszcze- } \\
\text { gólnych układów i organów), które w sensie } \\
\text { genetycznym, organicznym, strukturalnym } \\
\text { i funkcjonalnym posiadają wlaściwości czysto } \\
\text { biologiczne, a nie kulturowe }\end{array}$ & $\begin{array}{l}\text { - obejmuje tylko te zjawiska cielesne (dbalość } \\
\text { o rozwój fizyczny, sprawność ruchową, zdrowie } \\
\text { i fizyczną doskonalość), które lączą się ze sferą } \\
\text { aktywności człowieka w dziedzinie kultury } \\
\text { fizycznej, tj. m.in. sferą artystyczną, materialną } \\
\text { i instytucjonalną }\end{array}$ \\
\hline — zawiera całoksztalt osiągnięć medycyny & $\begin{array}{l}\text { - zawiera elementy osiągnięć medycyny (reha- } \\
\text { bilitacja ruchowa) }\end{array}$ \\
\hline
\end{tabular}

Tabela 1. Różnice w zakresie pojęć kultura somatyczna i kultura fizyczna

Żródlo: opracowanie własne na podstawie różnych autorów (m.in. Kosiewicz 2004: 72-73)

Kolejnym konkurencyjnym terminem dla kultury fizycznej jest kultura zdrowotna. Ważny głos w dyskusji nad wzajemnymi relacjami tych dwóch nazw (symbioza czy konkurencja?) zabral m.in. Zygmunt Jaworski (2009: 109-122). Wyniki jego analiz poświęconych dynamice procesu zmian w interpretacji i definiowaniu pojęć kultura fizyczna oraz kultura zdrowotna skłaniają do stwierdzenia, że wy stępują , "dwie prędkości" zmian: 
[...] dużą dynamiką postępu charakteryzują się teoretyczne rozważania dotyczące obu wspomnianych pojęć. W praktyce natomiast ich teoretyczne wykładnie i wynikające z nich wnioski w bardzo powolnym tempie przekładają się na społeczną świadomość ich wartości, a zwłaszcza na działania w codziennym życiu (Jaworski 2009: 109).

W korzystniejszej sytuacji znajduje sięjednakże pojęcie kultura zdrowotna, które ma przed sobą perspektywę rosnącej aprobaty spolecznej, gdy uwzględni się m.in. wzrost znaczenia edukacji zdrowotnej w szkolnictwie, co pokazuje obowiązująca podstawa programowa. W wypadku kultury fizycznej mamy natomiast do czynienia z deprecjacja i stopniową degradacja pojẹcia, gdyż rozbudowana podstawa teoretyczna nie niweluje kojarzenia kultury fizycznej głównie ze sprawnością fizyczną w wielu kręgach społecznych. Ponadto obserwujemy postępującą ekspansję „,brudnego" sportu wyczynowego, który ma w tym kontekście dzialanie kontrproduktywne. W tej sytuacji symbiotyczne funkcjonowanie kultury fizycznej i kultury zdrowotnej byłoby — zdaniem Jaworskiego - wskazane i korzystne z punktu widzenia obu nazw. Badania Jaworskiego obejmują zresztą także inne terminy należące do jednej rodziny semantycznej, aczkolwiek konkurencyjne wobec siebie, takie jak: kultura higieniczna, kultura sanitarna, kultura zdrowotna, higiena, wychowanie higieniczne, oświata sanitarna, oświata zdrowotna, wychowanie zdrowotne, edukacja prozdrowotna, edukacja zdrowotna.

Sporadycznie znajdują się też w światowej literaturze przedmiotu jeszcze inne propozycje pojęć pretendujących do bycia nadrzędnymi, takie jak: kultura ruchu/kultura ruchowa (niem. Bewegungskultur, która zostanie omówiona w dalszej części artykułu ze względu na swój niemiecki rodowód), kultura witalna (życia), kultura wysilku czy kultura walki. Tych dwóch ostatnich sformułowań używał Wiktor Junosza-Dąbrowski w pracy z 1928 r. pt. Co to jest sport, w swojej późniejszej twórczości natomiast wykorzystywal już termin kultura fizyczna - np. w książce z 1933 r. zatytulowanej Podstawy ideowe kultury fizycznej.

Ponadto w wielu wypadkach mamy do czynienia $\mathrm{z}$ wykorzystaniem techniki pars pro toto (lac. część za calość), czyli figury retorycznej polegającej na zastąpieniu nazwy (przedmiotu) przez nazwę jego części. Kultura fizyczna to bowiem pewien „konglomerat" - zbiór wielu elementów, takich jak: wychowanie fizyczne (omówione już wcześniej), sport, rekreacja ruchowa (fizy czna), rehabilitacja medyczna/ruchowa (fizjoterapia), turystyka. Żadnego komponentu, formy lub typu uczestnictwa w kulturze fizycznej (w terminologii językoznawczej: desygnatu kultury fizycznej) nie należy w żadnym wypadku rozumiećjako sformulowania synonimicznego do kultury fizycznej ani też żadne z tych pojęć nie może rościć sobie pretensji do hiperonimii. Wychowanie fizyczne to przecież pewne zamierzone i świadome dzialania ukierunkowane na ksztaltowanie stosunku do ciała i fizycznego funkcjonowania i mające na celu rozwój i podtrzymywanie sprawności oraz wytworzenie nawyków ruchowych. Rehabilitacja ruchowa to również pewne kompleksowe i zespolowe przedsięwzięcia na rzecz osoby niepełnosprawnej fizycznie, mające za zadanie przywrócenie utraconego z różnych przyczyn zdrowia lub sprawności fizy cznej. Rekreacja (lac. recreo — odnowić, ożywić) to czynny wypoczynek lub inaczej forma aktywności fizycznej, zapewniająca regenerację fizyczną i psychiczną 
przez wykonywanie czynności interesujących, przyjemnych, pozbawionych elementów obowiązku lub przymusu. W niektórych kontekstach istnieje jednak potrzeba skupienia się przede wszystkim na jednym czlonie i w rezultacie dochodzi do dezintegracji pojęcia głównego i intensywnej autonomizacji tego wlaśnie jednego elementu (najczęściej sprawa dotyczy sportu, fizjoterapii lub turystyki). Ze zlożoną i wieloczlonową naturą pojęcia kultura fizyczna wiąże się jeszcze inny, poważny problem: niewlaściwe jest wymienianie kultury fizycznej wraz z jednym elementem skladowym — jest to bląd logiczny. Tu warto przytoczyć myśl Godlewskiego: od początku istnial pewien swoisty konflikt między warstwą semantyczną nowotworu języ kowego, jakim jest kultura fizycz$n a$, a praktyką. Sprawa stala się do tego stopnia niewygodna, że konieczne były korekty, rozwiązania zastępeze i hybrydy terminologiczne w stylu: „kultura fizyczna i sport” czy „kultura fizyczna i turystyka”. W konsekwencji rozpocząl się proces pragmatyzacji pojęcia kultura fizyczna, a później jego alienacji (Godlewski 2005: 520).

Problem z rozmytym znaczeniem i zakresem pojęcia kultura fizyczna można podsumować, odwolując się do trafnego i - mimo uplywu czasu - wciąż aktualnego spostrzeżenia Krawczyka: dominująca rola myślenia w kategoriach „systemów” spowodowala, że kulturę fizyczną (a także wychowanie fizyczne) zaczęto sprowadzać do kategorii ćwiczeń fizycznych, wyrażających się w gimnastycznych, zabawowych (gry i zabawy ruchowe) bądź sportowych czy turystycznych formach (Krawczyk 1982: 2). Takie rozumienie kultury fizycznej pozostaje jako niemal obowiązujące do dziś zarówno w środowiskach naukowych (polskim i europejskim), jak i w świadomości społecznej.

\section{WSPÓLCZESNE UŻYCIE POJECIA KULTURA FIZYCZNA W RÓŻNYCH KONTEKSTACH SPOLECZNYCH I W WYBRANYCH JEZYKACH}

Przypomnijmy, iż wspólczesne rozumienie pojęcia dokonalo się w procesie ponadstuletniej ewolucji i walki o miejsce z innymi, konkurencyjnymi nazwami. W świadomości społecznej i językowej termin ten wspólistnieje z innymi nazwami, co omówiono szczególowo na przykladzie wybranych języków i przedstawiono zbiorczo w tabeli 2.

\begin{tabular}{|l|l|l|}
\hline Obszar występowania & Pojęcie nadrzędne & $\begin{array}{l}\text { Pojęcia podrzędne / Formy uczestnictwa / Wyrażenia } \\
\text { stosow ane (często) synonimicznie / Quasi-synonimy / } \\
\text { Pseudo-synonimy }\end{array}$ \\
\hline $\begin{array}{l}\text { Anglojęzyczny obszar } \\
\text { kulturowy }\end{array}$ & physical culture & $\begin{array}{l}\text { exercise science, gymnastics, sport/ sport science, } \\
\text { fitness, recreation, physical activity, movement, leisure, } \\
\text { training, competitive/ high performance / professional } \\
\text { sport, physiotherapy, rehabilitation (rehab), kinesiothe- } \\
\text { rapy, tourism / hospitality (+ turystyki przymiotnikowe, } \\
\text { np. dark tourism, active tourism) }\end{array}$ \\
\hline
\end{tabular}




\begin{tabular}{|c|c|c|}
\hline $\begin{array}{l}\text { Francuskojęzyczny } \\
\text { obszar } \\
\text { kulturowy }\end{array}$ & culture physique & $\begin{array}{l}\text { sport, sport pour tous, recreation, loisir, activite phy- } \\
\text { sique, rehabilitation, physiotherapie, kinesitherapie, } \\
\text { tourisme (+ turystyki przymiotnikowe, np. ecotourisme, } \\
\text { tourisme balneaire) }\end{array}$ \\
\hline $\begin{array}{l}\text { Niemieckojęzyczny } \\
\text { obszar } \\
\text { kulturowy }\end{array}$ & - & $\begin{array}{l}\text { Sport, Sportwissenschaft, Sport fur alle, Leistungssport / } \\
\text { Profisport, Leibesubung, Korperkultur, Bewegun- } \\
\text { gskultur, Turnen/Gymnastik, Training, Rehabilitation } \\
\text { (Reha), Physiotherapie (Krankengymnastik), Kine- } \\
\text { sitherapie, Tourismus / Touristik / Fremdenverkehr } \\
\text { (+ turystyki przymiotnikowe, np. Bildungstourismus, } \\
\text { sanfter Tourismus) }\end{array}$ \\
\hline $\begin{array}{l}\text { Polskojęzyczny obszar } \\
\text { kulturowy }\end{array}$ & kultura fizyczna & $\begin{array}{l}\text { gimnastyka (ćwiczenia fizyczne)/ fitness, wychowanie } \\
\text { fizyczne (WF), sport szkolny, sport dla wszystkich / } \\
\text { sport rekreacyjny/rekreacja (ruchowa/fizyczna), aktyw- } \\
\text { ność fizyczna/ruchowa/sportowa/rekreacyjna, sport } \\
\text { wyczynowy/ widowiskowy, rehabilitacja, fizjoterapia, } \\
\text { kinezyterapia, trening (sportowy/zdrowotny), kultura } \\
\text { (pro)zdrowotna, kultura somatyczna, turystyka (+ tu- } \\
\text { rystyki przymiotnikowe, np. agroturystyka, turystyka } \\
\text { aktywna) }\end{array}$ \\
\hline $\begin{array}{l}\text { Włoskojęzyczny obszar } \\
\text { kulturowy }\end{array}$ & - & $\begin{array}{l}\text { sport, sport per tutti, scienze motorie, attivita fisica / } \\
\text { ricreativa, ricreazione, movimento, culturismo / cultura } \\
\text { fisica, allenamento, sport competitivo / professionisti- } \\
\text { co / agonistico, riabilitazione, fisioterapia, kinesiterapia, } \\
\text { turismo (+ turystyki przymiotnikowe: turismo verde, } \\
\text { agriturismo itd.) }\end{array}$ \\
\hline
\end{tabular}

Tabela 2. Pole semantyczne wyrażenia kultura fizyczna w wybranych językach Źródło: opracowanie wlasne

W anglosaskim i amerykańskim obszarze pojęcie physical culture istnieje, ale mimo dobrej tradycji jest obecnie coraz rzadziej spotykane i zastępowane przez nośny i atrakcyjny termin sport oraz — w konkretnych kontekstach — przez terminy węższe.

W obszernym francuskojęzycznym obszarze kulturowym (nie zapominajmy o bylych francuskich koloniach) niezwykle popularny jest termin sport, obejmujacy znaczeniem niemal każdy rodzaj aktywności fizycznej w kontekście rekreacyjno-wolnoczasowym i profesjonalnym. Może wynikać to $\mathrm{z}$ faktu, iż samo slowo sport ma rodowód francuski (romański) i wielowiekową tradycję4.

\footnotetext{
${ }^{4}$ Kwestia historii i etymologii terminu sport jest ciekawa: początkowo to $w$ językach roman̉skich funkcjonuje nazwa czynności rekreacyjnych disporte, ale dopiero za pośrednictwem języka angielskiego ze slowa tego powstaje współczesny termin sport, który — jako zapożyczenie językowe — rozprzestrzenia się w wielu innych językach. Historyk i anglista Wojciech Lipónski (2004; 2014: 319-320) dokładnie prześledził zawiłe losy tego terminu. Prototyp słowa „sport” w brzmieniu disporte to pojęcie nieznane antykowi, powstałe dopiero w średniowieczu (choć nie można dokładnie ustalić, w której jego fazie) w językach romańskich
} 
W niemieckojęzycznym obszarze kulturowym panuje, jeśli wolno zaryzykować tak mocne stwierdzenie, wyjątkowy chaos pojęciowy i chyba nikt nie ma pomysłu, jak rozwiązać tę niewygodną sytuację terminologiczną. Funkcjonuje pojęcie Sportwissenschaft (niem. nauka o sporcie), ale jego przedmiotem zainteresowania jest jednak sport sensu stricto. Inny termin, nieco zapomniany lub świadomie wyparty z pobudek politycznych, Korperkultur, czyli dokladnie kultura ciala (kultura somatyczna / kultura cielesna), nie ma identycznego zakresu z kulturą fizyczną (o czym była mowa wcześniej). Pierwsze skojarzenie dotyczy zresztą często spotykanego wyrażenia Frei Korperkultur (FKK), czyli „wolnej kultury ciała” w znaczeniu nudyzmu, bardzo popularnego skądinąd w Niemczech. Powszechnie używa się też, po prostu, nazwy Sport. Starsze, tradycyjne nazwy to Leibesubungen (niem. wychowanie fizyczne, dosłownie ćwiczenie ciala) oraz Turnen czy Gymnastik, które jednak odnoszą się do pewnych form kultury fizycznej. Warto także przypomnieć propozycję autorstwa Austriaka Stefana Grossinga (1993): Bewegungskultur (niem. kultura ruchu / kultura ruchowa). Definicja autora przypomina polskie rozumienie kultury fizycznej: Bewegungskultur obejmuje wszystkie formy ludzkiego ruchu, podejmowanego codziennie w pracy i w czasie wolnym. Chodziloby zatem o pojęcie bardzo szerokie, mogące stanowić hasło nadrzędne. W ujęciu Grossinga kultura ruchowa traktowana jest jako styl życia (niem. Lebensstil). Istnieją 4 elementy kultury ruchowej, które się wzajemnie przenikają i uzupehniają (czy dopelniają): Sportkultur, Spielkultur, Gesundheitskultur i Ausdruckskultur. Kultura ruchowa jest częścią cielesności i wyrazem kultury ogólnej. Ruch daje każdemu czlowiekowi, szczególnie dzieciom i mlodzieży, impulsy do rozwoju, który należy kontynuować przez cale życie. Przez kulturę sportu (Sportkultur) ludzie zdobywają wszechstronne doświadczenie, budują i rozwijają sprawność. Nie chodzi o wyniki (inaczej niż to się dzieje w wypadku sportu wyczynowego), lecz o sposób i możliwości rozszerzania wlasnych ograniczeń fizycznych. Dzięki temu ludzie uczą się też, jak utrzymywać ciało w zdrowiu i jak się prawidłowo odżywiać. Tu występuje część wspólna (czy zazębiająca się) z kulturą zdrowia (Gesundheitskultur). Kultura ruchowa to również kultura gry (Spielkultur) wraz ze świadomie przyjętymi zasadami, duchem zespolu i rywalizacji, czynnym uczestnictwem, możliwością wygranej lub przegranej, językiem ciala, nawet ze sztuką cyrkową. Kultura ekspresji / wyrazu (Ausdruckskultur) to ostatni element: ruch jest sam w sobie pewnego rodzaju ekspresją wyrażaną poprzez ciało. Dzięki temu kultura ruchowa pomaga się

(francuski, włoski, prowansalski, hiszpański, kataloński, oksytański, rumuński) i oznaczające zabawę, przyjemność, radość. Jest to złożenie składające się z dwóch członów: łacińskiego przedrostka dis- określającego przemieszczenie, przesuwanie lub przenoszenie czegoś z jednego miejsca na drugie (analogicznie do przedrostków występujących w wyrazach dyslokacja czy dystans) oraz rdzenia odwołującego się do łacińskiego porta (brama, później także drzwi). A zatem disportae oznacza dosłownie czynność 'przenoszenia za bramę', a metaforycznie jest synonimem 'aktywnego spędzania czasu poza bramą, ćwiczenia i zabawy rekreacyjnej poza bramami miasta". Termin ten w XI w. przywędrował do języka angielskiego wraz z mówiącymi po francusku Normanami dokonującymi podboju Anglii. Pierwotna wersja angielska to desporte lub disporte, z czasem natomiast slowo to dotknęly dwie transformacje fonetyczne. Stosunkowo szybko nastąpil zanik wygłosowego (końcowego) e, a następnie doszło do afetyzacji przedrostka de/di. W ten sposób w średniowiecznej Anglii występować zaczęlo nowe słowo - sport. 
utożsamiać z wlasnym cialem. Propozycja Grossinga jest bardzo ciekawa, ale - jak slusznie podkreśla Piątkowska (2006: 86):, ,[...] bezkrytyczne przyjęcie stanowiska Grossinga wydaje się niemożliwe i absurdalne, gdyż odwołując się do samej definicji Bewegungskultur, pod hasłem wszelka działalność rozumieć można też pielęgnowanie rabatek czy budowanie dróg".

Wi Polsce oraz w innych krajach Europy Srodkowo-Wischodniej termin kultura fizyczna istnieje, ale ma swój „bagaż”, o czym obszernie pisano już poprzednio.

We wloskojęzy cznym obszarze kulturowym używa się sformułowania scienze motorie (wl. nauki o motoryczności) lub culturismo - taki termin jako odpowiednik angielskiego physical culture podaje Giuseppe Ragazzini (2002: 171) w swoim obszernym wlosko-angielskim i angielsko-wloskim slowniku sportu Dizionario dello sport. Niewątpliwie jest to jednak raczej dyscyplina sportowa, jaką jest kulturystyka (ang. body building; dokładnie ten sam odpowiednik znajdziemy także u Ragazziniego (2002: 30), i tak samo rozumiane jest zresztą pojęcie cultura fisica - kalka językowa $\mathrm{z}$ angielskiego, rzadko spotykane, choć intuicyjnie zrozumiale. A zatem również Włosi mają problem $\mathrm{z}$ wyborem odpowiedniego terminu. W wielu kontekstach używa się de facto mniej pojemnego, aczkolwiek nośnego, hasla sport (uważanego zresztą nadal za wyraz obcy i dlatego nieodmienianego w liczbie mnogiej: lo sport - gli sport).

We wszystkich językach objetych analiza istnieje wiele internacjonalizów pochodzenia grecko-łacińskiego, jak na przykład: rehabilitacja, fizjoterapia, kinezyterapia.

W tabeli 3 zebrano material obrazujący wykorzystanie terminu kuluura fizyczna oraz terminów bliskoznacznych (tu: konkurencyjnych) w odmiennych kontekstach spolecznych oraz w różnych językach (i tym samym w różnych krajach). 


\begin{tabular}{|c|c|c|}
\hline Kontekst spoleczny & $\begin{array}{l}\text { Użycie terminu } \\
\text { kultura fizyczna }\end{array}$ & Użycie pojęcia konkurencyjnego \\
\hline $\begin{array}{l}\text { Nazwy organizacji / } \\
\text { stowarzyszeń / } \\
\text { towarzystw }\end{array}$ & $\begin{array}{l}\text { Towarzystwo Krzewienia } \\
\text { Kultury Fizycznej, } \\
\text { Fundacja Rozwoju Kultu- } \\
\text { ry Fizycznej, } \\
\text { Związek Kultury Fizycz- } \\
\text { nej „Olimp”, } \\
\text { Stowarzyszenie Kultury } \\
\text { Fizycznej, Sportu i Tury- } \\
\text { styki Osób Niewidomych } \\
\text { i Stabowidzących „Cross" }\end{array}$ & $\begin{array}{l}\text { człon „wychowanie fizyczne”: np. Conseil Inter- } \\
\text { national pour l'Education Physique et le Sport } \\
\text { (i inne) } \\
\text { człon „sport / sportowy(a)”: np. Salezjańska } \\
\text { Organizacja Sportowa RP, Polski Związek Sportu } \\
\text { Niesłyszących', Deutscher Sportakrobatikbund², } \\
\text { Federazione Italiana Sport Invernali }{ }^{3} \text { (i inne) } \\
\text { człon „olimpijski / olimpiady”: np. International } \\
\text { Olympic Committee (+ podległe mu narodowe ko- } \\
\text { mitety olimpijskie, } 7 \text { stowarzyszeń regionalnych, } \\
\text { ok. } 100 \text { międzynarodowych związków sporto- } \\
\text { wych), Polski Komitet Paraolimpijski, Narodowe } \\
\text { Stowarzyszenie Olimpiady Specjalne (i inne) } \\
\text { człon „rehabilitacja”: np. Fundacja Aktywnej } \\
\text { Rehabilitacji (i inne) }\end{array}$ \\
\hline $\begin{array}{l}\text { Nazwy ministerstw / } \\
\text { departamentów / jed- } \\
\text { nostek organizacyj- } \\
\text { nych zajmującej się } \\
\text { kwestiami KF }\end{array}$ & $\begin{array}{l}\text { Rada do spraw Młodzie- } \\
\text { żowych i Kultury Fizycz- } \\
\text { nej (Polska, 1948-1989), } \\
\text { Glówny Urząd Kultu- } \\
\text { ry Fizycznej (Polska, } \\
\text { 1948-1989) }\end{array}$ & $\begin{array}{l}\text { człon ,sport": np. Ministry of family, culture, } \\
\text { sports and youth (Barbados), Ministere des sports, } \\
\text { de la jeunesse, de l'education populaire et de } \\
\text { la vie associative (Francja), Ministry for Sport } \\
\text { (Gibraltar), Ministry of youth affairs and sports } \\
\text { (Indie), Ministere des sports (Luksemburg), Bun- } \\
\text { desministerium fur Landesverteidigung und Sport } \\
\text { (Austria) } \\
\text { człon ,turystyka": np. Ministry of tourism, culture } \\
\text { and sport (Kanada) i wiele innych. }\end{array}$ \\
\hline $\begin{array}{l}\text { Nazwy dokumentów, } \\
\text { ustaw i rozporządzeń }\end{array}$ & $\begin{array}{l}\text { Ustawa z dnia } 18 \text { stycz- } \\
\text { nia } 1996 \text { r. o kulturze } \\
\text { fizycznej }\end{array}$ & $\begin{array}{l}\text { Ustawa z dnia } 25 \text { czerwca } 2010 \text { r. o sporcie } \\
\text { Ustawa z dnia } 29 \text { sierpnia } 1997 \text { r. o ushu- } \\
\text { gach turystycznych, Europejska Karta Sportu } \\
\text { z } 24.09 .1992 \text { r. (Rada Europy), Karta Olimpijska } \\
\text { Biała księga na temat sportu }\end{array}$ \\
\hline $\begin{array}{l}\text { Nazwy przedmiotów } \\
\text { szkolnych }\end{array}$ & - & $\begin{array}{l}\text { wychowanie fizyczne / PE (physical education)/ } \\
\text { education physique / educazione fisica / motoria } \\
\text { szkolne koło sportowe (SKS),PE/Gym (w USA), } \\
\text { Sport/Sportunterricht, scienze motorie }\end{array}$ \\
\hline $\begin{array}{l}\text { Nazwy szkół wyż- } \\
\text { szych i uniwersyte- } \\
\text { tów w obszarze KF }\end{array}$ & $\begin{array}{l}\text { Wyższa Szkoła Kultury } \\
\text { Fizycznej i Turystyki } \\
\text { im. Haliny Konopackiej }\end{array}$ & $\begin{array}{l}\text { człon „,wychowanie fizyczne”: np. Akademia Wy“ } \\
\text { chowania Fizycznego, Accademia di Educazione } \\
\text { Fisica di Roma (obecnie: Universita degli Studi di } \\
\text { Roma „Foro Italico”) i wiele innych } \\
\text { człon „,turystyka”: np. Wyższa Szkola Turystyki } \\
\text { i Rekreacji i wiele innych } \\
\text { człon „,sport”: np. Wyższa Szkola Edukacja } \\
\text { w Sporcie, Deutsche Sporthochschule, United } \\
\text { States Sports Academy, Polsko-Czeska Wyższa } \\
\text { Szkoła Biznesu i Sportu Collegium Glacense } \\
\text { i wiele innych }\end{array}$ \\
\hline
\end{tabular}




\begin{tabular}{|c|c|c|}
\hline $\begin{array}{l}\text { Nazwy obiektów } \\
\text { sportowych }\end{array}$ & - & $\begin{array}{l}\text { ośrodek sportu, ośrodek sportu i kultury, ośrodek } \\
\text { rekreacji, centrum / ośrodek zdrowia, } \\
\text { centrum / ośrodek spa / wellness / odnowy biolo- } \\
\text { gicznej, stadion, Arena / Park / Dome, fitness club } \\
\text { / klub, gimnazjon }\end{array}$ \\
\hline $\begin{array}{l}\text { Tytuly (przykładowe) } \\
\text { czasopism nauko- } \\
\text { wych zajmujących } \\
\text { się kwestiami KF* }\end{array}$ & $\begin{array}{l}\text { Physical Culture and } \\
\text { Sport. Studies and } \\
\text { Research, } \\
\text { Prace Naukowe Akademii } \\
\text { im. Jana Dlugosza w Cze- } \\
\text { stochowie. Seria: Kultura } \\
\text { Fizyczna, } \\
\text { Scientific Review of Physi- } \\
\text { cal Culture }\end{array}$ & 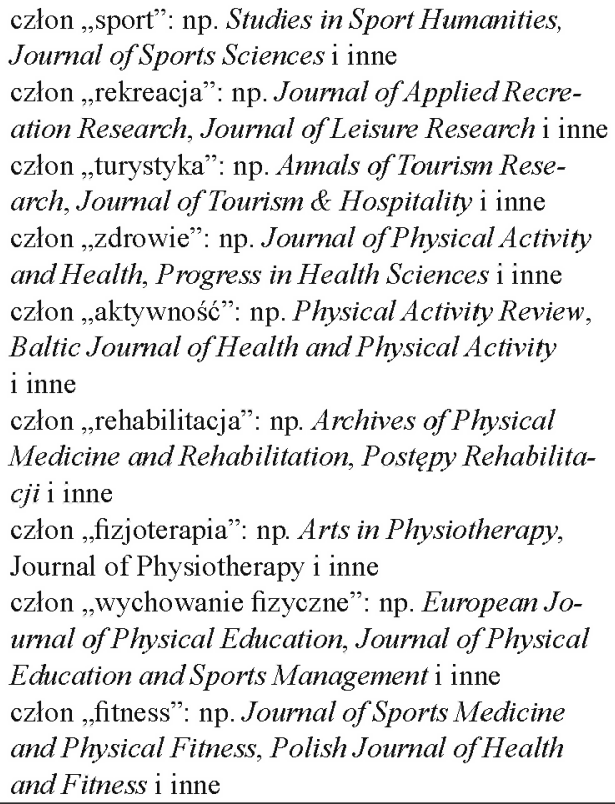 \\
\hline
\end{tabular}

Tabela 3. Obecność pojęcia kultura fizyczna i innych konkurencyjnych terminów w różnych kontekstach społecznych w wybranych językach

* Na podstawie wykazu punktowanych czasopism naukowych opublikowanego przez Ministerstwo Nauki i Szkolnictwa Wyższego 23.12.2015 r., <www.nauka.gov.pl/ujednolicony-wykaz-czasopism-naukowych/> oraz Polskiej Bazy Nauki, <www.pbn.gov.pl> [15.03.2017]

Źródło: opracowanie wlasne

Można stwierdzić, że w nazwach organizacji, stowarzyszeń, federacji, rad, towarzystw i ośrodków termin kultura fizyczna występuje sporadycznie i tylko w kontekście

5 To tylko przykladowy polski związek sportowy. 3 lutego 2016 r. minister sportu i turystyki Witold Bańka ogłosil wykaz 73 polskich związków sportowych, których nazwy zbudowane są przeważnie zgodnie ze wzorem „Polski Związek + nazwa dyscypliny sportowej”. W żadnej nazwie, pod żadną postacią, nie figuruje „kultura fizyczna".

${ }^{6}$ To tylko przykladowy niemiecki związek sportowy. Jest ich wiele i zawierają zazwyczaj w nazwie człon ,deutsche(r)" (niemiecki), nazwę dyscypliny sportowej oraz człon Band / Verband / Verein / Union.

${ }^{7}$ To tylko przykładowy wloski związek sportowy, ktỏrych jest łącznie około 65 (45 oficjalnie uznanych przez CONI oraz te poświęcone nieolimpijskim i nieklasycznym dyscyplinom sportowym, np. rafting, brydż, bowling, wspinaczka, bieg na orientację). Zazwyczaj zawierają w nazwie człon ,italiano(a)" (włoski), „federazione/club" oraz nazwę dyscypliny. 
polskim. W innych kręgach kulturowych króluje nośne haslo sport, nawet jeśli - de facto - dzialalność danej organizacji ma charakter szerszy.

W nomenklaturze administracji państwowej zarówno na poziomie wykonawczym, jak i legislacyjnym pojęcie kultura fizyczna wlaściwie nie występujejako takie, i uległo rozczłonkowaniu na części składowe (sport, turystyka itd.). Warto się przyjrzeć ulokowaniu poszczególnych elementów kultury fizycznej w strukturze administracji rządowej w różnych państwach (notabene to material wystarczający prawdopodobnie na osobny artykul). Wiersz drugi tabeli 3 poświęcony jest nazwom ministerstw, departamentów oraz urzędów państwowych. Jak widać nie istnieje Ministerstwo (ani Departament czy Urząd) Kultury Fizycznej, a poszczególne składniki KF „tułają” się po przeróżnych resortach. Prawidłowość taka odnosi się zarówno do rządowej administracji w Polsce, jak i w innych krajach. Turystyka „wędruje” między dzialem ekonomicznym / gospodarczym, zagospodarowania przestrzennego, transportu, środowiska, sportu, kultury / dziedzictwa kulturowego, sport natomiast, jeśli nie stanowi jednostki autonomicznej, bywa dokooptowany do edukacji narodowej, turystyki, polityki regionalnej, obrony narodowej lub spraw wewnętrznych (w ty m ostatnim wypadku niewidoczny w nazwie) ${ }^{8}$. W wielu krajach sprawy sportu polączone są z kwestiami mlodzieży (Gruzja, Korea Południowa, Francja, Iran, Indie, Malezja, Azerbejdżan, Ghana, Mołdawia, Turcja). W nazwach dokumentów termin KF występuje sporadycznie, np. w nazwie jednej ze starszych polskich ustaw. Mamy jednak do czynienia z deprecjacją i ,urzędową degradacją" pojęcia kultura fizyczna i z wyraźną tendencją do zastąpienia go przez termin sport: za taki akt należy uznać Ustawę z dnia 25 czerwca 2010 r. o sporcie (Dz.U. 2010, nr 127, poz. 857). Wspomniana ustawa jest zresztą konsekwencją imperialnej ekspansji MKOl-u, zmierzającej do wykreowania sportu jako uniwersalnego pojęcia aktywności ruchowej (Jaworski 2010: 6-8). W innych ważnych aktach dotyczących interesującej nas dziedziny termin KF jest nieobecny, Co ciekawe, ręczne wyszukiwanie sformułowania kultura fizyczna w samym tekście ważnych dokumentów, takich jak Karta Olimpijska lub Biała księga na temat sportu (raport Komisji Europejskiej; w terminologii Unii Europejskiej biale księgi to dokumenty zawierające opracowanie urzędowe, koncepcyjne propozycje działań i zadań odnoszące się do poszczególnych dziedzin polityki unijnej) nie przyniosło pozytywnego rezultatu — wszechobecne jest slowo sport.

Na poziomie szkolnictwa powszechnie używane są dwie opcje: wychowanie fizyczne lub sport, nie ma natomiast przedmiotu kultura fizyczna.

W nazwach państwowych szkół wyższych (kolegiów, uniwersytetów czy akademii), polskich oraz zagranicznych, pojęcie kultura fizyczna nie pojawia się w ogóle. Nie ma Aka-

${ }^{8}$ Tylko w ostatnich latach sport kilkakrotnie zmienial miejsce w ministerstwach polskich: Ministerstwo Edukacji Narodowej i Sportu (2001-2005); Ministerstwo Sportu (2005-2007); Ministerstwo Sportu i Turystyki (2007-) oraz wloskich: Dipartimento per le politiche giovanile e le attivita sportive (2006-2008); autonomiczne Ufficio per lo sport (2008-2012) w czwartym rządzie Silvia Berlusconiego; Dipartimento per gli affari regionali, il turismo e lo sport (2012-2013); Dipartimento per gli affari regionali, le autonomie e lo sport (2013-). 
demii Kultury Fizy cznej, bywają natomiast akademie i uniwersy tety sportowe. W sześciu miastach Polski funkcjonują Akademie Wychowania Fizycznego 9 . W oficjalnej nazwie zawiera się zazwyczaj nazwę miasta goszczącego (w Warszawie, Krakowie, Poznaniu, Gdańsku, we Wroclawiu, w Katowicach) oraz ewentualnie imię i nazwisko patrona lub zalożyciela uczelni, które może być poprzedzone sformulowaniem „imienia” (np. im. Józefa Pilsudskiego, im. Jędrzeja Śniadeckiego, im. Bronisława Czecha, im. Eugeniusza Piaseckiego, im. Jerzego Kukuczki). Należy ponadto zauważyć, że gdańska uczelnia wprowadziła do nazwy czlon sport: Akademia Wychowania Fizycznego i Sportu im. Jędrzeja Śniadeckiego w Gdańsku. Należy to chyba potraktowaćjako zabieg marketingowy, szczególnie że program studiów tej uczelni nie różni się znacznie od curriculum uczelni „tylko" wychowania fizycznego (w nazwie). W nazwach branżowych uczelni prywatnych czy niepublicznych (jakby na wzór uczelni zachodnich) powszechnie występują terminy sport lub turystyka. W Polsce funkcjonuje także niepubliczna Wyższa Szkoła Kultury Fizycznej i Turystyki im. Haliny Konopackiej. W wypadku zagranicznych uczelni albo pojawia się wyraz sport w samej nazwie, albo gdy studiuje się na wydziale lub w instytucie uniwersytetu ogólnego (tytuł uniwersytetu jest prestiżowy), wtedy w nazwie danego departamentu najczęściej widnieje haslo sport (przykladowo: Institut fur Sport und Sportwissenschaft na Universitat Heidelberg, Universitatssportinstitut w Wiedniu, Scienze Motorie e dello Sport na Universita Cattolica del Sacro Cuore w Mediolanie).

W nazwach obiektów sportowych nie stwierdzono czlonu kultura fizyczna. W nazwach placówek dedykowanych dla aktywnych klientów najczęściej występuje hasło fitness (club / klub / studio / centrum / ośrodek). W.języku potocznym mówi się, że idzie się „na silownię" (,to the gym”) lub „na silkę” (innowacja zgodna z tendencją do ekonomiczności języka), a nie do „ośrodka kultury fizycznej” czy „,centrum formacji cielesnej”. Silownia kojarzy sięjednak przede wszy stkim z treningiem silowym, kulturystyką i z malą liczbą urządzeń cardio (a także ze zdecydowaną przewaga mężczyzn wśród użytkowników). Są też obiekty szeroko rozumianej odnowy biologicznej, w których nazwie występuje hasło spa (z lac. sanus per aquam, 'zdrowy poprzez wodę') lub wellness (ang. 'dobrostan'). Ciekawą tendencję można zaobserwować w nazewnictwie wielofunkcyjnych budowli przeznaczonych do rozgrywania zawodów różnych dyscyplin sportowych oraz innych masowych imprez widowiskowych lub komercyjnych (np. koncerty czy targi). Do niedawna obiekty takie nazywano w zasadzie wylącznie ,stadionami” (ang. stadium, niem. Stadion, fr. stade, wl. stadio), odwohjąc się — klasycznie — do starożytnych korzeni

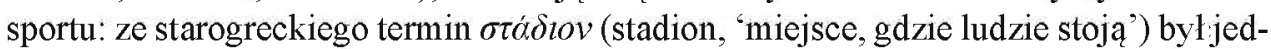
nostką dlugości uży waną w starożytnej Grecji i równą 600 stopom (ok. $180 \mathrm{~m}$ ), a bieżnia greckich stadionów miala wlaśnie dlugość równąjednemu stadionowi (Engels 1985: 300). Obecnie często spotyka się człon arena (Allianz Arena w Monachium, Donbas Arena w Doniecku, Arena Zabrze, PGE Arena, Amsterdam ArenA, Commerzbank-Arena we Frankfurcie nad Menem), który także ma obcojęzyczną etymologię (arena z łacińskiego to 'piasek') i slowo to oznaczalo w starożytności otoczone widownią koliste miejsce,

${ }^{9}$ Istnieją także zamiejscowe wydzialy, np. w Białej Podlaskiej oraz w Gorzowie Wielkopolskim. 
na którym odbywaly się różnego typu pokazy, np. cyrkowe lub sportowe. Jest to zatem termin pojemniejszy semantycznie. W nazewnictwie obiektów sportowych arena to neosemantyzm, którego atutem jest prawdopodobnie identyczna pisownia w większości języków świata oraz „efekt świeżości” w porównaniu z klasycznym stadionem. Inna konkurencyjna dla stadionu nazwa to park: Croke Park w Dublinie, Villa Park w Birmingham, Signal Iduna Park w Dortmundzie. W Stanach Zjednoczonych w nazwach największych obiektów sportowych dominuje slowo dome (z ang. 'sklepienie, kopula'): Superdome w Nowym Orleanie, Metrodome w Minneapolis, RCA Dome w Indianapolis, Georgia Dome w Atlancie, Alamodome w San Antonio. Na podstawie powyższej przywołanych nazw obiektów sportowych, a także dodając do tego sztandarowy przykład warszawski, należy zwrócić uwagę na jeszcze jedną istotną zmianę w nazewnictwie. Jako iż struktura wlaścicielska stadionów jest zróżnicowana, a koszt utrzymania bardzo wysoki, popularnym zabiegiem naszych czasów jest uwzględnianie sponsora w nazwie obiektu. Różne przedsiębiorstwa stają się partnerem tytularnym obiektu, w rezultacie czego styszymy: PGE Narodowy (Warszawa) czy Mercedes-Benz-Arena (Stuttgart).

Ostatni wiersz tabeli 3 poświęcony jest tytułom naukowych czasopism branżowych. Ze względu na ich mnogość, różnorodność oraz nieustannie wzrastającą liczbę i interdyscyplinarność nie sposób przywolać wszystkich publikacji, w których porusza się kwestie - skądinąd bardzo szeroko rozumianej - kultury fizycznej. Badaniem objęto punktowane czasopisma naukowe (uwzględnione w wykazie z grudnia 2015 r.) poświęcone interesującemu nas zagadnieniu (132 czasopisma). W tabeli przedstawiono skróconą wersję wykazu, pokazując pewne tendencje. W tytułach czasopism goszczą przede wszystkim takie słowa klucze, jak: sport, rehabilitacja, turystyka, fizjoterapia, rekreacja, fitness, zdrowie, wychowanie fizyczne, aktywność fizyczna / ruchowa. Niewiele jest tytulów zawierających nazwę kultura fizyczna - trzy. Należy się zastanowić nad przyczynami takiego stanu rzeczy. Na pewno jest to pojęcie dosyć szerokie, a niektóre czasopisma są bardziej wyspecjalizowane lub/i interdyscyplinarne, w związku z czym ich zakres jest — odpowiednio - węższy. Chodzi tu np. o tematykę turystyki, antropomotoryki, rehabilitacji medycznej / medycyny rehabilitacyjnej / fizjoterapii lub historii / socjologii albo psychologii sportu. Nie ulega jednak wątpliwości, że termin KF nie zostal wyeksploatowany. Istnieje zaledwie kilka pozycji, w których pojawia się kultura fizyczna, a biorąc pod uwagę bogactwo językowe przekładające się na wielorakie opcje nazwania czasopisma (jako czlon glówny: Annals / Roczniki, Review / Przegląd, Journal, Folia, Acta, Rozprawy / Studies / Issues in itd.; dodatkowe epitety afiliacyjne akcentujące międzynarodowość typu International, World, European itp., miejsca wydania American, Polish itp. lub odniesienie do konkretnej uczelni czy wydawcy), liczba możliwych do wyobrażenia konstelacji jest kilkadziesiąt razy większa. W tym kontekście można przywołać wnioski z przeprowadzonego przez Jaworskiego (2009: 109-122) badania jakościowego poświęconego tytułom konkretnych publikacji naukowych w obszarze kultury fizycznej. Na podstawie frekwencji występowania takich pojęć, jak: kultura higieniczna, kultura sanitarna, kultura zdrowotna, higiena, wychowanie higieniczne, oświata sanitarna, oświata zdrowotna, wychowanie zdrowotne, edukaça prozdrowotna, 
edukacja zdrowotna, w tytulach publikacji Jaworski (2009) podejmuje się trudnej próby ustalenia chronologii ich funkcjonowania w Polsce i stwierdza, że pewne pojęcia pojawialy się epizodycznie, inne w tym samym czasie byly używane w warunkach koegzystencji lub wręcz zamiennie. Finalnie pokazuje przejście od terminu higiena (dominującego w latach przedwojennych) do terminu kultura zdrowotna (upowszechniającego się od lat 70. m.in. za sprawą propagowanego przez samego Jaworskiego (1977) projektu symbiozy kultury zdrowotnej i fizycznej). Następowalo ono na zasadzie modyfikacji i transformacji pojęć, obejmując coraz rozleglejsze zakresy wiedzy i działań przeciwko zagrożeniom oraz w celu wzmocnienia zdrowia czlowieka w wymiarze mikro (indywidualnym, jednostkowym) i makro (publicznym, ogólnospolecznym). Termin kultura fizyczna ma znaczenie marginalne. Ponadto na przykladzie konkretnej — interesującej nas — socjologii szczególowej (socjologia kultury fizycznej / sportu) Krawczyk (2011: 28) pokazuje różnice w terminologii stosowanej przez badaczy spolecznych w Europie Zachodniej i Ameryce oraz w krajach będących pod ich silnym wplywem: posługują się oni nazwą socjologia sportu, a nie socjologia kultury fizycznej (Heinemann 1998; Weiss 1999). Termin socjologia kultury fizycznej uksztaltowal się i ugruntowal natomiast w krajach Europy Środkowej i Wischodniej oraz zostal przyjęty w obszarze ich naukowego oddzialywania. Wedlug Krawczyka

[... ] warto jednakże zauważyć, że — co prawda sporadycznie — termin ten [tj. kultura fizyczna — J.M.] pojawia się w ostatnich latach także wśród tej pierwszej grupy socjologów, szczególnie w Finlandii. I odwrotnie: nazwa socjologia sportu rozprzestrzenila się bardzo szybko na drugim, wymienionym przez nas obszarze, m.in. w Polsce (Krawczyk 2011: 28).

\section{DYSKUSJA}

Autor artykułu nie chce być odebrany jako niepoprawny optymista - krytyk i „kamodzieja", ubolewający nad obecnym stanem rzeczy i nawohujący do tradycjonalizmu i konserwatyzmu, lecz poniekąd jest to nieuniknione. Kultura fizyczna, szczególnie na poziomie terminologicznym, podlega intensywnemu procesowi dezintegracji i autonomizowania się poszczególnych jej typów, a na czolo wysuwa się sport, który rozwija się niezmiernie szybko i wzbudza powszechne zainteresowanie spoleczne, jednostkowe i medialne. W wielu kontekstach to, co jest — racjonalnie rozumując - kulturą fizyczną, nazywa się sportem (nie dotyczy to rzeczjasna każdego użycia tego ostatniego terminu). Mamy zatem do czynienia z zabiegiem pars pro toto, zagrażającym wypieranemu pojęciu nadrzędnemu. Rezygnacja z pojęcia kultura fizyczna oznacza okrojenie, zaniedbanie korzeni, kulturowe zubożenie i często wręcz wypaczenie sensu szeroko rozumianej prozdrowotnej aktywności fizycznej i troski o rozwój psychofizyczny. Rodzi się pytanie, co jest shużebne wobec czego.

Zastanawiającejest wykorzystanie sformulowania „kultura fizy czna i sport”, którejest niepoprawnym użyciem hiperonimu i.jednego z hiponimów — tego modnego, nośnego i współcześnie propagowanego. Najlepszym sposobem ujęciajednocześnie takich elemen- 
tów, jak oświata, aktywność, zdrowie, sport, jest przecież wlaśnie pojemny i zaniedbany termin kultura fizyczna. Należaloby się zastanowić, jakie dzialania mogloby sprawić, by pojęcie kultura fizyczna miało przed sobą perspektywę rosnacej spolecznej aprobaty.

Ciekawe wydaje się to, że „sportowe kwestie językowe” nie są mieszkańcom obojętne. Za wyraz tego można uznać obywatelski sprzeciw wobec prób nadania stadionom niefortunnych nazw (kontrowersja dotyczyla np. propozycji Floating Arena dla obiektu sportowego w Szczecinie). W takich wypadkach o ekspertyzę proszona jest Rada Języka Polskiego, która wielokrotnie przyczynila się do uniknięcia ,potworka językowego". Analogiczne insty tucje funkcjonują w innych krajach. Można sobie wyobrazić, jak trudne zadanie ma konserwatywna Academie Française odpowiedzialna za niedopuszczanie do obiegu zagranicznego slownictwa we współczesnej terminologii sportowej czy — szerzej - sferze kultury fizycznej, tak obfitującej przecież w anglicyzmy.

$\mathrm{Na}$ podstawie przeprowadzonej analizy można stwierdzić, iż jednym z nielicznych bastionów terminu kultura fizyczna jest polskie środowisko naukowe (nie mylić z opinią publiczną, w której pojęcie to jest mało rozpowszechnione). Współcześni polscy teoretycy omawianej dziedziny wydają się mocno przywiązani do tej klasycznej terminologii i można by wręcz upatrywać szansę na wyróżnienie się Polski w tym zakresie: jako kontynuatora tradycyjnego pojęcia. Niemniej jednak polskojęzyczne teksty nie trafiają nigdy do międzynarodowego obiegu, jeśli nie są przelożone na inny język (najczęściej angielski) i w związku z tym tradycyjna nomenklatura i tak gubi się w thumaczeniu.

\section{WNIOSKI}

Artykul poświęcony jest wszechstronnej analizie zestawienia kultura fizyczna. Temat ujęto w wielu aspektach wewnętrzno- $\mathrm{i}$ zewnętrznojęzykowych, w tym etymologicznym, semantycznym, pragmaty cznym, komunikacyjnym, kulturowym, historycznym, a nawet politycznym. W konkluzji omawianą sytuację można sprowadzić do kilku głównych stwierdzeń. Pojemny semantycznie termin kultura fizyczna nie jest rozpowszechniony w międzynarodowym obiegu. Są do niego przywiązani polscy uczeni humaniści zajmujący się procesem naukotwórczym, ale w środowisku naukowym na Zachodzie wydaje się on prawie nieobecny. Rezygnacja z tradycyjnego i szerokiego terminu wprowadza chaos pojęciowy, który niejednokrotnie prowadzi do zamieszania i uniemożliwia rzetelne i miarodajne prowadzenie międzynarodowych badań oraz porównywanie i interpretację wyników. Istnieje wiele konkurencyjnych lub pozornie synonimicznych wyrażeń, ale ich zakres znaczeniowy jest inny (zazwyczaj mniejszy). W licznych kontekstach triumfy święci nośne hasło sport, którego desygnat nie jest jednak tożsamy z tym oznaczanym przez termin kultura fizyczna. 


\section{BIBLIOGRAFIA}

Adams M. 2009: Mr. America: How Muscular Millionaire Bemarr Macfadden Transformed the Nation Through Sex, Salad, and the Ulimate Starvation Diet, New York: Harper Collins.

Bale J. 2002: Imagined Obmpians: Body Culture and Colonial Representation in Rwanda, Minneapolis: University of Minnesota Press.

Bittne r I. 1995: Kultura fizyczna jako sfera psychofizycznej aktywności czlowieka. Studia teoretyczno-metodologiczne, Lódź: Wydawnictwo Uniwersytetu Lódzkiego.

Demel M. 1974: Pojęcie kultury fizycznej, [w:] Krawczyk Z. (red.), Filozofia i socjologia kultury fizycznej. Wybór tekstów, Warszawa: Wydawnictwo Naukowe PWN, 215-218.

Eich berg H. 1998: Body Culture: Essays on Sport, Space and Identity, London: Routledge.

Eichberg H., Hansen J. (red.) 1989: Korperkulturen undIdentitat. Versuche einer alternativen Aufmerksamkeit, Munster: Lit Verlag (Association Internationale d'Anthropologie Corporelle).

Engels D. 1985: The Length of Eratosthenes' Stade, American Journal of Philology 106(3), $298-311$.

Ernst R. 1991: Weakness is a Crime: The Life of Bernarr Macfadden, Syracuse (NYi): Syracuse University Press.

Gaj J., Hądzelek K. 1991: Dzieje kultury fizycznej w Polsce w XIXiXXwieku. Koncepcje, uwarunkowania i efekty instytucjonalnej dzialalności, Poznań: AWF.

Godlewski P. 2005: „Kultura fizyczna” — termin i system na usługach marksistowskiej ideologii, [w:] Dziubiński Z. (red.), Sport jako kulturowa rzeczywistość, Warszawa: Salezjańska Organizacja Sportowa Rzeczypospolitej Polskiej, 520-527.

Golka M. 2008: Socjologia kultury, Warszawa: Wydawnictwo Naukowe Scholar.

Griffith M.R. 2000: Apostles of Abstinence: Fasting and Masculinity during the Progressive Era, American Quarterty 52(4), 599-636.

Grossing S. 1993: Bewegungskultur undBewegungserziehung, Schorndorf: Hofmann.

Haag H., Mess F., Haag G. 2012: Dictionary. Spont-PhysicalEducation-Sport Science, Berlin: Logos Verlag.

Heinemann K. 1998: Einfuhrung in die Soziologie des Sports (Sport und Sportunterricht), Schorndorf: Hofmann.

Herder J.G. 1962: Myśli o filozofii dziejów, tłum. J. Gałecki, wstęp E. Adler, t. 1, Warszawa: Państwowe Wydawnictwo Naukowe.

Jaczynowski L. 2000: System nauk o kulturze fizycznej (próba uporządkowania), Zagadnienia Naukoznawstwa $1,25-43$

Jankowski K.W. 2011: Państwo, polityka i kultura fizyczna, [w:] Dziubiński Z., Krawczyk Z. (red.), Socjologia kultury fizycznej, Warszawa: AWF, 284-297.

Jaworski Z. 1977: Propedeutyka kultury zdrowotnej ifizycznej w systemie edukacji. Zarys przyszlościowego modelu, Warszawa: AWF.

Jaworski Z. 2009: Transformacja pojęć: od higieny do kultury zdrowotnej, Zdrowie - Kultura Zdrowotna-Edukacja IV, 109-122.

Jaworski Z. 2010: Imperium Sportu - refleksje niedokończone, Lider 11, 6-8.

Kloskowska A. 1981: Socjologia kultury, Warszawa: PWN.

Korsgaard O. 1982: Kampen om kroppen. Dansk idrets historie gennem 2000 ar, Copenhagen: Gyldendal.

Kosiewicz J. 2004: Filozoficzne aspekty kultury fizycznej i sportu, Wrocław: Wydawnictwo BK. 
Krawczyk Z. 1982: Kształtowanie się teorii kultury fizycznej, Kultura Fizyczna 10-12, 2-6.

Krawczyk Z. 1983: O kulturze fizycznej. Studia i szkice, Warszawa: Wydawnictwo AWF.

Krawczyk Z. 1997: Kultura fizyczna, [w:] Krawczyk Z. (red.), Encyklopedia kultury polskiej XX wieku. Kultura Fizyczna, sport, Warszawa: Instytut Kultury, 11-12.

Krawczyk Z. 2011: Powstanie i rozwój socjologii kultury fizycznej, [w:] Dziubiński Z., Krawczyk Z. (red.), Socjologia kultury fizycznej, Warszawa: AWF, 19-37.

Lipoński W. 2004: Rochwist i palant. Studium etnologiczne dawnych polskich sportów i gier ruchowych na tle tradycji europejskiej, Poznań: AWF.

Lipoński W. 2014: Najdawniejsze tradycje i przemiany języka sportu w Europie, [w:] Dziubiński Z., Rymarczyk P. (red.), Kultura fizyczna a zmiana spoleczna, Warszawa: Akademia Wychowania Fizycznego im. Józefa Piłsudskiego, Salezjańska Organizacja Sportowa Rzeczypospolitej Polskiej, 313-327.

Mauss M. 1973: Techniques of the Body (Les techniques du corps), Economy and Society 2, 70-88.

Mrozek D.J. 1987: The Scientific Quest for Physical Culture and the Persistent Appeal of:Quackery, Journal of Sport History 14(1), 76-82.

Nielsen N.K. 1993: Krop og oplysning. Om kropskultur i Danmark 1780-1900, Odense: Odense Universitetsforlag.

Pawłucki A. 2015: Nauki o kulturze fizycznej, Kraków: Oficyna Wydawnicza Impuls.

Piątkowska M. 2006: Rozumienie pojęcia kultura fizyczna na świecie, Kultura Fizyczna 9-12, 83-86.

Ragazzini G. 2002: Dizionario dello sport inglese-italiano italiano-inglese, Bologna: Zanichelli.

Sironen E. 1995: Urheilun aika ja paikka, Jyvaskyla: LIKES.

Szymański L. 2004: Kultura fizyczna i turystyka w Polsce Ludowej 1944-1989, Wrocław: Studia i Monografie AWF we Wroclawiu 74.

Todd J. 1987: Bernarr Macfadden: Reformer of:Feminine Form, Joumal of Sport History 14(1), 61-75.

Urniaż J. 2015: Kultura fizyczna jako przedmiot naukowego poznania, Rozprawy Naukowe Akademii Tychowania Fizycznego $w$ Warszawie 48, 17-24.

Vestergärd Madsen B. 2003: Oplysning i bevcegelse. Kultur, krop og demokrati i den folkelige gymnastik, Arhus: Klim.

Wedemeyer-Kolwe B. 2004: „Der neue Mensch“. Korperkultur im Kaiserreich und in der Weimarer Republik, Wurzburg: Konigshausen \& Neumann.

Weis s O. 1999: Einfuhrung in die Sportsoziologie, Wien: WUV-Universitatsverlag.

Wharton J.C. 1982: Crusaders for Fitness: The History of American Health Reformers, Princeton NJ: University Press Princeton.

Woh1 A. 1974: Kultura fizyczna i jej specyfika, [w:] Krawczyk Z. (red.), Filozofia i socjologia kultury fizycznej, Warszawa: Wydawnictwo Naukowe PWN, 219-221.

Wood C. 2003: Bernarr Macfadden: A Study in Success, Whitefish (MT): Kessinger Publishing LLLC.

\section{ŹRÓDLA}

Bańko M. (red.) 2000: Inny slownikjęzyka polskiego, Warszawa: Wydawnictwo Naukowe PWN.

Biala księga na temat sportu 2007, Luksemburg: Urząd Oficjalnych Publikacji Wspólnot Europejskich. Doroszewski W. (red.) 1958-1969: Slownik języka polskiego, Warszawa: Wydawnictwo Naukowe PWN. 
Dubisz S. (red.) 2003: Uniwersalny stownik języka polskiego, Warszawa: Wydawnictwo Naukowe PWN. Karta Olimpijska 2013, Lozanna: Międzynarodowy Komitet Olimpijski.

Stownik jezyka polskiego PWN 2007, wyd. 3, oprac. zbiorowe, Warszawa: Wydawnictwo Naukowe PWN. Ustawa z dnia 18 stycznia 1996 r. o kulturze fizycznej (Dz.U. 1996, nr 25, poz. 113, rozdz. 1 art. 1). Ustawa z dnia 29 sierpnia 1997 r. o uslugach turystycznych (Dz.U. 1997, nr 133, poz. 884) Ustawa z dnia 25 czerwca 2010 r. o sporcie (Dz.U. 2010, nr 127, poz. 857).

Wykaz punktowanych czasopism naukowych Ministerstwa Nauki i Szkolnictwa Wyższego z 23.12.2015 r., <www.nauka.gov.pl/ujednolicony-wykaz-czasopism-naukowych/>.

\section{ABSTRACT}

\section{The term of physical culture from a sociolinguistic perspective}

Keywords: physical culture, culture, sport, language, sociolinguistics.

The present paper addresses the issues of etymology, history, meaning and range of the term "physical culture" as well as the contemporary use of the very name in different social contexts and in chosen languages covered by the analysis (Polish, English, German, French and Italian and sporadically other languages). The research findings evidence that we may have to do with a term threatened with extinction because, for a variety of reasons, the most comprehensive term for a holistic care and improvement of human health and capacity performance, all motor activities, sport, movement therapy, physical exercises and education tend to be replaced by 'false' synonyms and by hyponyms whose semantic field is included within that of hypernymic physical culture. 